\title{
Resistance and effect of insecticide-treated coffee berries of different varieties to the penetration of Hypothenemus hampei (Coleoptera: Curculionidae: Scolytinae)
}

\author{
Salmo de Melo Davi Júnior ${ }^{(1 D}$, Walyson Silva Soares ${ }^{1}$ (D), Fernando Juari Celoto ${ }^{1}$ (D), Flávio Lemes Fernandes² (iD), \\ Mariana Martins Fernandes Oliveira ${ }^{2}$ (iD), Gabriel Buso Borges Botrel ${ }^{2}$ (D)
}

\author{
${ }^{1}$ Universidade Federal de Uberlândia/UFU, Instituto de Ciências Agrárias, Uberlândia, MG, Brasil \\ ${ }^{2}$ Universidade Federal de Viçosa/UFV-CRP, Instituto de Ciências Agrárias, Rio Paranaíba, MG, Brasil \\ Contact authors: salmo.junior@outlook.com; walysonagronomia@gmail.com; fjceloto@ufu.br; flaviofernandes@ufv.br; mariana.m.oliveira@ufv.br; gabriel.botrel@ufv.br \\ Received in January 4, 2021 and approved in July 28, 2021
}

\begin{abstract}
The control of Hypothenemus hampei, coffee berry borer (CBB) is difficult as the insects infest inside coffee berries and are thus protected from agrochemicals. Coffee varieties with an increased penetration time by $\mathrm{H}$. hampei can help control this pest tends to be exposed insecticide action for long time. Therefore, this study aimed to determine the time taken by $\mathrm{H}$. hampei to entirely penetrate berries of different coffee varieties and whether insecticides have any influence on the penetration time. Thus, twenty five berries of 27 coffee varieties in the green phenological stage were introduced in rubber caps, with the berry crown exposed.. From this experiment, seven varieties were selected for another bioassay, with insecticides being sprayed on the berries. Copulated female $H$. hampei were released on the berry, and the penetration time was assessed. Finally, a free-choice test to verify $H$. hampei food preference was performed, using the same seven coffee varieties. The insects took longer to penetrate the Arara, Catuaí Vermelho IAC 144, and Guará coffee-variety berries. Moreover, all coffee varieties treated with the insecticide cyantraniliprole inhibited penetration by $H$. hampei. Most coffee varieties treated with insecticides showed a prolonged penetration time by $\mathrm{H}$. hampei compared to the same untreated ones, except for the chlorpyrifos insecticide in the Catuaí IAC 144 and IAC 62 varieties. Additionally, H. hampei showed no feeding preference among the different tested coffee varieties.
\end{abstract}

Key words: Coffea arabica; Chemical control; Food preference.

\section{INTRODUCTION}

The coffee berry borer CBB, Hypothenemus hampei (Coleoptera: Curculionidae: Scolytinae), is considered one of the most aggressive pests that attack coffee berries. $H$. hampei pierces the crown region, penetrates the fruit pulp and seed, and feeds on its endosperm. Thus, this insect can be located in different positions of the fruit (Jaramillo et al., 2005; Alba-Alejandre; Alba-Tercedor; Vega, 2018; Infante; Pérez;Vega, 2014; Vega et al., 2015). In addition, H. hampei continues its biological cycle within the seed: females lay from 1 to 3 eggs a day, the larvae hatch and pupate, and then adults emerge in under higher temperature conditions (Romero; Cortina, 2007; Constantino et al., 2021). Mating occurs inside the seed between siblings; after copulation, the females leave the damaged berry to feed and lay their eggs in a different, undamaged berries (Aristizábal; Bustillo; Arthurs, 2016; Ceja-Navarro et al., 2015). The time it takes for the coffee berry borer to penetrate the fruit, which is essential information for pest management, is still poorly understood. The time $H$. hampei takes to fully penetrate berries can vary among many other variables coffee varieties, depending on the chemical, anatomical, and physiological characteristics of the fruit, for example the dry matter content $(>20 \%)$ so that $H$. hampei it can pass most of its life within the coffee fruit (Infante; Pérez;Vega, 2014).
The berries' anatomical variations, such as the diameter of the crown, may influence the penetration behavior of $H$. hampei (Machado et al., 2017). Chemical characteristics are also important determinants of insect behavior (Bruce; Pickett, 2011), especially that of the females, which can sense the different volatile compounds released by attacked and intact fruit and differentiate among them (Jaramillo et al., 2013). Coffee berries from different varieties may interact with insecticide molecules, which can interfere with the insect's biology; insects might take longer to penetrate the fruit or even die in the effort. This interaction has been seen in species such as peach (Prunus persica L.) and sweet pepper (Capsicum annum $\mathrm{L}$.) that have fruits that accumulate insecticide residues differently in their surface (Ahlawat et al., 2019; Žunić et al., 2020). Thus, the interaction of coffee fruit with insecticides can lead to differences in the penetration rate of the coffee borer in the fruit and help to understand this insect behavior in fruit of different coffee varieties.

H. hampei management is mostly performed with organophosphate and pyrethroid insecticides in Brazil, the residues of which remain on the surface of the fruit and can be toxic to humans and other non-target organisms present in the environment (Mekone; Ambelu; Spanogle, 2015). Integrated Pest Management relies on molecules that are increasingly selective, less toxic to humans, with low residual value in food and are highly effective in pest control, thus being 
considered as model molecules for the development of more effective insecticides (Jeckler, 2016). Diamides, for example, are part of a chemical group with high insecticidal potential. This insecticide acts on $\mathrm{Ca}^{2+}$ channels (ryanodine receptors), causing muscle paralysis and feeding inhibition, being marginally toxic to mammals and selective to natural enemies (Shad; Shad, 2020). Chlorantraniliprole and cyantraniliprole are examples of insecticides based on diamide that caused mortality and reduced $H$. hampei motor and respiratory activities in several studies (Gonring et al., 2019; Nakao; Banba, 2015; Nakao; Banba, 2016; Plata-Rueda et al., 2019). Another broad-spectrum insecticide, Metaflumizone, belongs to the semicarbazone group presenting very low acute and chronic toxicity to mammals (Hempel et al., 2007; Takagi et al., 2007).

Therefore, this study aimed to evaluate the time taken by $H$. hampei females to penetrate in berries of different coffee varieties and whether insecticides could interfere in this process. Ultimately, the results will be used to identify coffee varieties with berries that are resistant to $H$. hamperi penetration, as well as select new insecticides that can be associated with these borer-resistant varieties.

\section{MATERIAL AND METHODS}

The study was carried out at the Integrated Pest Management Laboratory at the Federal University of Viçosa, Rio Paranaíba Campusin Brazil. Three bioassays were performed to assess berry resistance to $H$. hampei and the effect of different insecticides. In the first bioassay, $H$. hampei penetration time was determined in berries of several coffee varieties, without insecticides. In the second bioassay, berry preference by $H$. hampei females was assessed among the tested coffee varieties. The third bioassay followed the same procedure used in bioassay 1, with the application of insecticides on the coffee berries. All bioassays were performed in a completely randomized design.

Berries of 27 varieties of C. arabica were collected from a coffee crop located at the Abaeté dos Mendes farm in the municipality of Rio Paranaíba-MG, coordinates $19^{\circ} 08^{\prime} \mathrm{S}$ and $46^{\circ} 08^{\prime} \mathrm{W}$. The varieties were: Acauã, Acauã Novo, Arara, Asabranca, Bem-te-vi Vermelho (19/17 and 19), Yellow Bourbon IAC J9, Catiguá MG2, Catuaí Amarelo IAC 17, Catuaí Amarelo IAC 62, Catuaí Amarelo IAC Caratinga, Catuaí Vermelho IAC 144, Catuaí Vermelho IAC 99, Catucaí Vermelho 20/15, Catucaí Vermelho 24/137, Catucaí Amarelo 2SL, Guará, IAC 125 RN, IPR 100, IPR 103, IPR 107, MGS Aranãs, MGS Paraíso 2, Mundo Novo 379-19, Oeiras MG 6851, Rubi-MG 1192, Saíra, and Topázio MG 1190. The berries were harvested manually in the green phenological stage (110 days after flowering). Insecticides had not been applied in the crop nor the nearby plots. Approximately 100 fruit of each variety were collected and stored in $2 \mathrm{~L}$ plastic bags. After harvesting, the berries were sent to the LMIP and maintained under refrigeration $\left(10^{\circ} \mathrm{C}\right)$ to delay fermentation, before the bioassays start.

$H$. hampei adults were collected from dried berries from commercial arabica coffee crops (Coffea arabica), Catuaí Vermelho IAC 144, at Abaeté dos Mendes farm, located in the municipality of Rio Paranaíba, MG, coordinates $19^{\circ} 08^{\prime} \mathrm{S}$ and $46^{\circ} 08^{\prime} \mathrm{W}$. Collected berries were then packed in plastic bags and sent to the laboratory.

H. hampei females were removed from the collected berries by making a longitudinal cut in the fruit, $1 \times 10^{-3}$ to $2 \times 10^{-}$ ${ }^{3} \mathrm{~m}$ below the crown, and using a stylus to extract the insects without harming them. After the insects were removed, they were placed in a Petri dish $\left(9.0 \times 10^{-2} \times 1.5 \times 10^{-2} \mathrm{~m}\right)$ for later use.

\subsection{Assessment of penetration time in berries without insecticide}

Five berries of each variety (in the expansion fruits phenological stage, 110 days after flowering) were introduced in rubber caps of penicillin flasks, with the crown upwards and arranged equidistantly in a circle in a Petri dish $\left(9.0 \times 10^{-2} \mathrm{x}\right.$ $\left.1.5 \times 10^{-2} \mathrm{~m}\right)$. Each berry was considered an experimental unit. After removing the insects from the berries and keeping them fasting for 2 hours, one $H$. hampei female per fruit was released on the berry's crown and observed; when the female started to perforate the crown, the time for penetration into the fruit was computed. Penetration time was considered to be the period the insect drilled the berry until it was not possible to observe any part of the insect's body horizontally (Position b) to the position of the berry's crown(Jaramillo et al., 2005). ANOVA was used to determine significant differences between the groups, and means were compared with the Scott-Knott cluster test at $5 \%$ probability and significance level.

\subsection{Free-choice preference test}

This bioassay aimed to identify $H$. hampei feeding preference. Seven coffee varieties (Arara, Catuaí Vermelho IAC 62, Catuaí Amarelo IAC Caratinga, Catuaí Vermelho IAC 144, IPR 100, IPR 107, and Saíra) were selected from bioassay one. The Scott-Knott test was used to determine the coffee varieties. Two varieties were chosen because $H$. hampei took longer to penetrate the berry (the highest average among all groups), and one coffee variety from each of the significantly different groups regarding penetration time.

Four arenas were prepared, one per Petri dish $\left(1.5 \times 10^{-1} \times 1.5 \times 10^{-2} \mathrm{~m}\right)$, with the selected seven varieties of coffee (Arara, Catuaí IAC 62, Catuaí IAC Caratinga, Catuaí IAC 144, IPR 100, IPR 107, and Saíra). In this bioassay, styrofoam was used as a base; seven holes were made in the arenas' outer rims, and an EVA sheet was placed and fixed 
at the Styrofoam top to obtain a smooth surface and prevent $H$. hampei from entering the holes. One berry of each of the seven varieties was inserted in each orifice. Subsequently, ten females of H. hampei were released on the center of the arena, one at a time.

The insects were released into the arena using a paintbrush. Once one insect was released, the Petri dish was covered and left on the bench until the insect started perforating one of the berries. Once drilling started, the perforated berry(along with the insect) was replaced by another berry of the same variety. Then, another insect was released in the arena. The process was repeated with ten insects in each of the four prepared arenas. The bioassay was conducted in environmental conditions at temperatures of $25 \pm 2{ }^{\circ} \mathrm{C}, 75 \pm 5 \%$ $\mathrm{RH}$ and photoperiod 12:12 $\mathrm{h}$ [L:D]. The collected data were analyzed to determine whether they met the assumptions of analysis of variance, and they were subjected to ANOVA and Tukey's test at 5\% significance level.

\subsection{Assessment of penetration time in berries with insecticide}

This bioassay was conducted similarly to bioassay one, and insecticides were sprayed on coffee berries. Seven coffee varieties (Arara, Catuaí IAC 62, Catuaí IAC Caratinga, Catuaí IAC 144, IPR 100, IPR 107, and Saíra) were selected from bioassay one. Two varieties from the group with the best results (longest time by $H$. hampei females to penetrate the berries) were selected, along with one variety from each statistically different mean groups according to the Scott-Knott grouping. Thus, it was possible to determine the penetration time of the insect in the fruit in the presence of insecticides.

For this, 20 berries per selected variety were placed in Petri dishes $\left(9.0 \times 10^{-2} \times 1.5 \times 10^{-2} \mathrm{~m}\right)$. The experiment followed a simple factorial design (seven varieties $\times$ four insecticides + control group), with five replicates; each berry was considered an experimental unit. The chosen insecticides were acetamiprid + bifenthrin (UPL do Brasil Indústria e Comércio de Insumos Agropecuarios SA; rate: $0.2 \mathrm{~kg} \mathrm{ha}^{-1}, 0.5 \mathrm{~kg}$ a.i. ha ${ }^{-1}$ acetamiprid associated to $0.5 \mathrm{kga}$ i ha ${ }^{-1}$ bifenthrin), chlorpyrifos (NUFARM Indústria Química e Farmacêutica SA;rate: $1.5 \mathrm{~L} \mathrm{ha}^{-1}, 720 \mathrm{~mL}$ a.i. ha ${ }^{-1}$ ), cyantraniliprole (DuPont do Brasil SA, rate: $1.5 \mathrm{~L} \mathrm{ha}^{-1}$, $0.15 \mathrm{kga}^{2}$. ha ${ }^{-1}$ ), and metaflumizone (BASF SA, rate: $2 \mathrm{~L} \mathrm{ha}^{-1}$, $480 \mathrm{~mL}$ a.i. ha $\left.{ }^{-1}\right)$. All insecticides were diluted in distilled water and $1 \mathrm{~mL}$ was applied directly over the coffee fruit, $0.15 \mathrm{~m}$ away, using an aerograph airbrush (MP-1003, Wimpel) calibrated at a pressure of 40 psi. All applications were performed in the laboratory where the berries remained for $30 \mathrm{~min}$ for complete drying. The study was conducted in incubator regulated at temperature of $25 \pm 1^{\circ} \mathrm{C}, 65 \pm 10 \% \mathrm{RH}$ and photoperiod $12: 12 \mathrm{~h}$ [L:D].Then, a female H. hampei was released on the berry, and the penetration time was assessed. The evaluation was conducted for up to ten hours-considering the moment the insect started the penetration process until its completion. The Petri dishes were kept on a laboratory bench under the same conditions that of insecticide application on the berries. The obtained data were analyzed to determine whether they met the assumptions of analysis of variance, and if so, they were subjected to analysis of variance and Tukey's test at $5 \%$ significance.

\section{RESULTS}

In bioassay one, we evaluated how long female $H$. hampei would take to completely penetrate berries from different coffee varieties without any insecticide application. The coffee varieties with a longer penetration time by $H$. hampei were: Arara (5.7 h), Guará (5.6 h), and Catuaí Vermelho IAC 144 (5.4 h) (Figure 1). The penetration time of the coffee berry borer in these three varieties was approximately twice as long as the penetration time in the Catiguá MG2, IPR 103, IPR 107, and MGS Ananãs varieties. The IPR 103, IPR 107, and MGS Ananãs varieties showed shorter $H$. hampei penetration times: 2.8, 2.9; and $3.0 \mathrm{~h}$, respectively. Although all coffee berry borer was collected from IAC144 in the field, this variety was among the three in which the insect took the longest to penetrate the berries (Figure 1) completely.

In free-choice preference test, no differences were found between the averages of the varieties evaluated $(\mathrm{F}=$ $0.8519 ; \mathrm{df}=6.28 ; P=0.5415$ ).

In evaluation of penetration time in berries with insecticide, we verified that most varieties treated with insecticides affected $H$. hampei females. The insects showed longer penetration in the insecticide-treated berries than in the untreated ones (control group) (Table 1), except for the Catuai IAC 144 and IAC 62 varieties sprayed with chlorpyrifos. We observed that all tested varieties the application of insecticide increase the time of penetration. The insecticide cyantraniliprole inhibited the entry of $H$. hampeiin all tested berries (Table 1). The insecticides metaflumizone and acetamiprid + bifenthrin increased the $H$. hampei penetration time in the Arara $(7.9 \mathrm{~h}$ and $7.8 \mathrm{~h})$ and Catuaí IAC $144(7.7 \mathrm{~h}$ and $7.6 \mathrm{~h})$ varieties, followed by chlorpyrifos in Arara (6.2 h) (Table 1).

\section{DISCUSSION}

The disparity in H. hampei penetration time in different coffee varieties may be associated with the intrinsic genetic characteristics of each coffee variety. Genetic variability affects plant characteristicssuch as productivity and fruit maturation cycle (Santin et al., 2019), drink quality (Barbosa et al. 2019; Lemos et al., 2020), produced secondary metabolites (Becerra et al., 2019), and berry crown diameter (Machado et al., 2017). Thus, the extended penetration time by $H$. hampei in Arara, Guará and Catuaí Vermelho IAC 144 varieties may be linked to genes that regulate pericarp characteristics that might hinder H. hampei, increasing the time females would take to drill into the berry. 


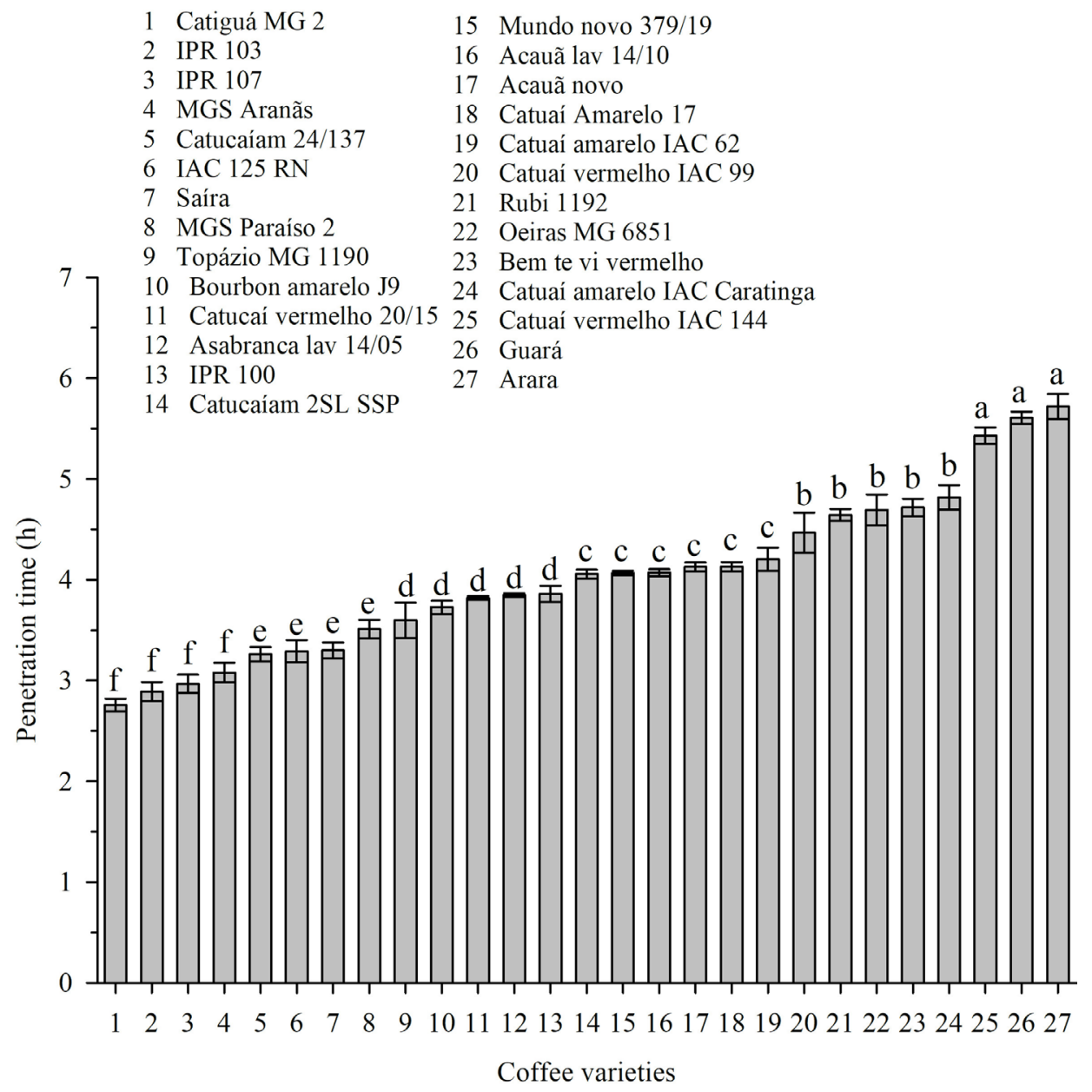

Figure 1: Penetration time (hours) (average \pm standard error) of Hypothenemus hampei females in Coffea arabica varieties.

Table 1: Average penetration time (hours) of Hypothenemus hampei females in insecticide-treated coffee berries.

\begin{tabular}{cccccccc}
\hline \multirow{2}{*}{ Treatment } & \multicolumn{7}{c}{${ }^{1}$ Coffee variety } \\
\cline { 2 - 7 } & Arara & $\begin{array}{c}\text { Catuaí Vermelho } \\
\text { IAC144 }\end{array}$ & $\begin{array}{c}\text { Catuaí Vermelho } \\
\text { IAC 62 }\end{array}$ & $\begin{array}{c}\text { Catuaí Amarelo } \\
\text { IAC Caratinga }\end{array}$ & IPR 100 & IPR 107 & Saíra \\
\hline Control & $5.7 \mathrm{Ac}$ & $5.4 \mathrm{Ab}$ & $4.2 \mathrm{Cc}$ & $4.8 \mathrm{Bc}$ & $3.9 \mathrm{Cd}$ & $3.0 \mathrm{Dd}$ & $3.3 \mathrm{Dc}$ \\
Cyantraniliprole & N.p. & N.p. & N.p. & N.p. & N.p. & N.p. & N.p. \\
Chlorpyrifos & $6.2 \mathrm{Ab}$ & $5.7 \mathrm{Bb}$ & $4.5 \mathrm{Cbc}$ & $5.5 \mathrm{Bb}$ & $4.5 \mathrm{Cc}$ & $3.6 \mathrm{Dc}$ & $4.5 \mathrm{Ca}$ \\
Acet.+Bif. & $7.8 \mathrm{Aa}$ & $7.6 \mathrm{Aa}$ & $5.8 \mathrm{Ca}$ & $6.2 \mathrm{Ba}$ & $5.4 \mathrm{Cb}$ & $4.3 \mathrm{Db}$ & $4.1 \mathrm{Db}$ \\
Metaflumizone & $7.9 \mathrm{Aa}$ & $7.7 \mathrm{Aa}$ & $4.6 \mathrm{DEb}$ & $5.6 \mathrm{Cb}$ & $6.2 \mathrm{Ba}$ & $4.8 \mathrm{D}$ & $4.3 \mathrm{Eab}$ \\
\hline VC $(\%)$ & & & 3.90 & & & \\
\hline
\end{tabular}

Acet. + bif. $=$ Acetamiprid + bifenthrin; $\mathrm{Np}=$ No-penetration; ${ }^{1}$ Average of characteristics followed by the same uppercase letters in the rows and lowercase letters in the columnsdo not differ by the Tukey test $(P>0.05) ;{ }^{2}$ Catuaí varieties.

Indeed, the increase in the penetration time by $H$. hampei provides coffee farmers an advantage as the insects will be exposed for a longer period to external conditions, mainly the temperature that can affect the development of the coffee borer and its interaction with the plant (Constantino et al., 2021). Thus, integrated pest management techniques can be more effective. The Arara, Catuaí Vermelho IAC 144 and Guará varieties, with the longest penetration times, are highly recommended varieties, mostly when other methods effective in controlling $H$. hampei are used, such as the application of entomopathogenic fungi (Edgington et al., 2000 ), with an $88 \%$ mortality rate; further, only $5 \%$ of the surviving insects are able to drill into the berry and reach the seed endosperm (Mota et al., 2017). Notably, these methods 
can be even more efficient when applied to varieties with the studied characteristic.

When considering the addition of insecticides, the effect was very positive as the increase in the penetration time by $H$. hampei in all evaluated varieties was significant. This increase in time reveals a possible change in the insect's biological parameters since the application of chemical compounds may affect behavior, especially feeding (Celestino et al., 2015), as some insecticides directly affect the digestive system, consequently decreasing the mass gaining capacity of the insects. Thus, longevity and fertility rate of $H$. hampei might have been reduced. In this context, the results reported by Dastranj et al. (2018) corroborate with this hypothesis, as they found a decrease by $30 \%$ and $17 \%$, respectively, in the body mass of Plutella xylostella (Lepidoptera: Plutellidae) and Pieris rapae (Lepidoptera: Pieridae) larvae.

Insecticides can cause indigestion through ingestion and contact. In the short term, mortality from ingestion is much more significant. When associated (ingestion and contact, whether direct or tarsal contact only), there is an additive effect and insecticide's toxicity becomes more effective due to the chronic effect of insecticides, causing more mortality (Řezáč; Řezáčová; Heneberg, 2019).

The insecticide cyantraniliprole inhibited the entrance of the coffee berry borer, thus altering its behavior. The same modification was found by Joseph et al. (2020). The authors observed that the insecticide reduced pest feeding, being very effective in the coffee berry borer management. The efficiency in the control of insect pests by cyantraniliprole is supported by studies with other crops, such as rice and strawberries. Cyantraniliprole was considered more effective compared to chlorpyrifos, bifenthrin, and chlorantraniliprole; it was also considered a low-risk insecticide, both in toxicological and environmental terms (Joseph et al., 2020; Mao et al., 2019; Renkena et al., 2020).

Another feature that is worth mentioning regarding cyantraniliprole is its ability to cause damage and changes in DNA, which can cause desired changes in the biological parameters and behavioral characteristics of insects (Qiao et al., 2019), such as decreased feeding and female fertility rate. However, when it comes to chemical control, insects developing resistance to certain active ingredients is a concern. Studies already reported insects developing resistance to insecticides such as chlorantraniliprole and chlorpyrifos (Mallott et al., 2019; Wang; Lou; Su, 2019), the latter not controlling $H$. hampei as effectively as metaflumizone. No insect resistance to metaflumizone has been reported(Sun et al., 2019), despite the fact that this insecticide is not as effective as abamectin or azadirachtin (Amizadeh et al., 2019).

No food preference was found among $H$. hampei insects in the selected coffee varieties, agreeing with these results bySara et al. (2010). Targeted studies aiming at the identification of volatiles emitted by different varieties are necessary (Brassioli-Moraes et al., 2019), as they provide significant results to determine the preference of $H$. hampei for different coffee varieties.

\section{CONCLUSIONS}

The Arara, Catuaí Vermelho IAC 144, and Guará varieties showed the best results related to the longest penetration time of $H$. hampei in coffee berries, with $5.7 \mathrm{~h}, 5.6$ $\mathrm{h}$ and $5.4 \mathrm{~h}$, respectively. Consequently, present better effect for entomopathogenic fungi for longer penetration time of $\mathrm{H}$. hampei.

The insecticide cyantraniliprole inhibited $H$. hampei penetration in berries of all tested varieties. Moreover, berries from most varieties treated with insecticides increased penetration time by the coffee berry borer compared to the untreated ones, except for chlorpyrifos in the Catuaí IAC 144 and IAC 62 varieties.

Additionally, no feeding preference of the coffee berry borer was observed among the different varieties tested.

\section{ACKNOWLEDGMENTS}

To Conselho Nacional de Desenvolvimento Científico e Tecnológico (CNPq), Coordenação de Aperfeiçoamento de Pessoal de Nível Superior" (CAPES) and Fundação de Amparo à Pesquisa do Estado de Minas Gerais (FAPEMIG) for financial support.

\section{REFERENCES}

AHLAWAT, S. et al. Persistence and decontamination studies of chlorantraniliprole in Capsicum annum using GC-MS/ MS.Journal of Food Science and Technology, 56:29252931, 2019.

ALBA-ALEJANDRE, I.; ALBA-TERCEDOR, J.; VEGA, F. E. Observing the devastating coffee berry borer (Hypothenemus hampei) inside the coffee berry using microcomputed tomography. Scientific Report, 8:17033, 2018.

AMIZADEH, M. et al. Interaction between the entomopathogenic nematode, Steinernema feltiae and selected chemical insecticides for management of the tomato leafminer, Tuta absoluta. Biocontrol, 64(6):709$721,2019$.

ARISTIZÁBAL, L. F.; BUSTILLO, A. E.; ARTHURS, S. P. Integrated pest management of coffee berry borer: Strategies from Latin America that Could Be Useful for Coffee Farmers in Hawaii. Insects, 7(1):6, 2016. 
BARBOSA, I. P. et al. Sensory quality of Coffea arabica L. genotypes influenced by postharvest processing. Crop Breeding and Applied Biotechnology, 19(4):428-435, 2019.

BEZERRA-GAMBOA, R. et al. Metabolomic markers for the early selection of Coffea canephora plants with desirable cup quality traits. Metabolites, 9(10):214, 2019.

BRASSIOLI-MORAES, M. C. et al. Influence of constitutive and induced volatiles from mature green coffee berries on the foraging behaviour of female coffee berry borers, Hypothenemus hampei (Ferrari) (Coleoptera: Curculionidae: Scolytinae). Arthropod-Plant Interactions, 13(3):349-358, 2019.

BRUCE, T. J. A.; PICKETT, J. A. Perception of plant volatile blends by herbivorous insects-Finding the right mix. Phytochemistry, 72(13):1605-1611, 2011.

CEJA-NAVARRO, J. A. et al. Gut microbiota mediate caffeine detoxification in the primary insect pest of coffee. Nature Communication, 6:7618, 2015.

CELESTINO, F. N. et al. Toxicity of castor oil to coffee berry borer [Hypothenemus hampei (Ferrari) (Coleoptera: Curculionidae: Scolytinae). Coffee Science, 10(3):329-336, 2015.

CONSTANTINO, L. M. et al. Coffee berry borer (Hypothenemus hampei) emergence from ground fruits across varying altitudes and climate cycles, and the effect on coffee tree infestation. Neotropical Entomology, 50:374-387, 2021.

DASTRANJ, M. et al. Inhibitory effects of an extract from non-host plants on physiological characteristics of two major cabbage pests. Bulletin of Entomological Research, 108(3):370-379, 2018.

EDGINGTON, S. et al. Photoprotection of Beaveries Basina: Testing simple formulations for control of the coffee berry borer. International Journal of Pest Management, 46(3):169-176, 2000.

GAMBOA-BECERRA, R. et al. Metabolomic Markers for the Early Selection of Coffea canephora Plants with Desirable Cup Quality Traits. Metabolites, 9(10):1-19, 2019.

GONRING, A. H. R. et al. Comparative bioassay methods to determine diamide susceptibility for two coffee pests. Crop Protection, 121:34-38, 2019.

GUIDE, B. A. et al. Selection of entomopathogenic nematodes and evaluation of their compatibility with cyantraniliprole for the control of Hypothenemus hampei. Semina-Ciências Agrárias, 39(4):1489-1502, 2018.
HEMPEL, K. et al. Toxicological properties of metaflumizone. Veterinary Parasitology,150(3):190-195, 2007.

INFANTE, F.; PÉREZ, J.; VEGA, F. E. The coffee berry borer: The centenary of a biological invasion in Brazil. Brazilian Journal of Biology, 74(3):125-126, 2014.

JARAMILLO, J. et al. Coffee berry borer joins bark beetles in coffee klatch. Plos One, 8(9):1-15, 2013.

JARAMILLO, J. et al. Biological control of the coffee berry borer Hypothenemus hampei (Coleoptera: Curculionidae) by Phymastichuscoffea (Hymenoptera: Eulophidae) in Colombia. Bulletin of Entomological Research, 95(5):467-472, 2005.

JECKLER, P. Progress of modern agricultural chemistry and future prospects. Pest Management Science, 72(3):433$455,2016$.

JOSEPH, S. V. Repellent effects of insecticides on Stephanitis pyrioides Scott (Hemiptera: Tingidae) under laboratory conditions. Crop Protection, 127:104985, 2020.

LEMOS, M. F. et al. Chemical and sensory profile of new genotypes of Brazilian Coffea canephora. Food Chemistry, 310:125850, 2020.

MACHADO, C. M. S. et al. Genetic diversity among 16 genotypes of Coffea arabica in the Brazilian Cerrado. Genetics and Molecular Research, 16(3):1-13, 2017.

MALLOTT, M. et al. A flavin-dependent monooxygenase confers resistance to chlorantraniliprole in the diamondback moth, Plutella xylostella. Insect Biochemistry and Molecular Biology, 115:103247, 2019.

MAO, K. et al. Dynamics of insecticide resistance in different geographical populations of Chilo suppressalis (Lepidoptera: Crambidae) in China 2016-2018. Journal of Economic Entomology, 112(4):1866-1874, 2019.

MEKONEN, S.; AMBELU, A.; SPANOGLE, P. Effect of household coffee processing on pesticide residues as a means of ensuring consumers' safety. Journal of Agricultural and Food Chemistry, 63(38):8568-8573, 2015.

MOTA, L. H. C. et al.Autoinoculation trap for management of Hypothenemus hampei (Ferrari) with Beauveria bassiana (Bals.) in coffee crops. Biological Control, 111:32-39, 2017.

NAKAO, T.; BANBA, S. Minireview: Mode of action of meta-diamide insecticides. Pesticide Biochemistry and Physiology, 121(1):39-46, 2015. 
NAKAO, T.; BANBA, S. Broflanilide: A meta-diamide insecticide with a novel mode of action. Bioorganic $\boldsymbol{\&}$ Medicinal Chemistry, 24(3):372-377, 2016.

PLATA-RUEDA, A. et al. Exposure to cyantraniliprole causes mortality and disturbs behavioral and respiratory responses in the coffee berry borer (Hypothenemus hampei). Pest Management Science, 75(8):2236-2241, 2019.

QIAO, Z. et al. Growth, DNA damage and biochemical toxicity of cyantraniliprole in earthworms (Eisenia fetida). Chemosphere, 236:124328, 2019.

RENKENA, J. M. et al. Efficacy of insecticides for seasonlong control of thrips (Thysanoptera: Thripidae) in winter strawberries in Florida. Crop Protection, 127:104945, 2020 .

ŘEZÁČ, M.; ŘEZÁČOVÁ, V.; HENEBERG, P. Neonicotinoid insecticides limit the potential of spiders to re-colonize disturbed agroecosystems when using silk-mediated dispersal. Scientific Reports, 9:12272, 2019.

ROMERO, J. V.; CORTINA, H. A. Tablas de vida de Hypothenemus hampei (Coleoptera: Curculionidae: Scolytinae) sobre tres introducciones de café. Revista Colombiana de Entomología, 33(1):10-16, 2007.

SANTIN, M. R. et al. Yield, maturation cycle, and estimates of genetic parameters of robusta coffee genotypes under irrigation in the Cerrado. Crop Breeding and Applied Biotechnology, 19(4):387-394, 2019.
SARA, G. H. et al.Coffee berry borer resistance in coffee genotypes. Brazilian Archives of Biology and Technology, 53(2):261-268, 2010.

SHAD, R. M.; SHAD, S. A. House fly resistance to chlorantraniliprole: Cross resistance patterns, stability and associated fitness costs. Pest Management Science, 76(5):1866-1873, 2020.

SUN, X. X. et al. Resistance risk evaluated by metaflumizone selection and the effects on toxicities over other insecticides in Spodoptera exigua (Lepidoptera: Noctuidae). Journal of Economic Entomology, 112(5):2354-2361, 2019.

TAKAGI, K. et al. Discovery of metaflumizonea novel semicarbazone insecticide. Veterinary Parasitology, 150(3):177-181, 2007.

VEGA, F. E. et al. Draft genome of the most devastating insect pest of coffee worldwide: the coffee berry borer, Hypothenemus hampei. Scientific Reports, 5:12525, 2015.

WANG, X.; LOU, L.; SU, J. Prevalence and stability of insecticide resistances in field population of Spodoptera litura (Lepidoptera: Noctuidae) from Huizhou, Guangdong Province, China. Journal of Asia-Pacific Entomology, 22(3):728-732, 2019.

ŽUNIĆ, A. et al. The efficacy of novel diamide insecticides in Grapholita molesta suppression and their residues in peach fruits. Plant Protection Science, 56(1):46-51, 2020 . 